\title{
三次元レーダー雨量計情報の可視化
}

\section{VISUALIZATION OF THE INFORMATION FROM A THREE-DIMENSIONALLY SCANNING RADAR RAINGAUGE}

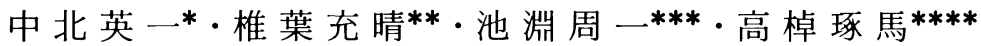 \\ By Eiichi NAKAKITA, Michiharu SHIIBA, Shuichi IKEBUCHI and Takuma TAKASAO
}

\begin{abstract}
We developed several colour graphic screens which can visually represent both the distribution of echo intensity and the shape of the three dimensionally spread precipitation field, in order to investigate how fine resolution the radar information has.

By the use of VCAPPI (Various Constant Altitude Plan Positions Indicator), which we developed from CAPPI, we can visually investigate three dimensional characteristics of the precipitation phenomena in meso- $\beta$ scale. Furthermore, by the use of FVCAPPI (VCAPPI for an arbitrary specified domain) and RRHI (in the form of the arrangement of fifteen RHIs), we can visually investigate characteristics in meso- $\gamma$ scale.

In the case of very heavy rainfall which arose along Baiu front on the 21 July in 1986, from FVCAPPI and RRHI we can find a convective echo consists of several echo cells in various life stages. This means the convective echo is from a multi-cell storm. This fact can be also verified from RHTI (Range Height Time Indicator), which can visually represent the time series of an echo pattern in an arbitrary vertical section, by setting the vertical section along the storm moving direction.
\end{abstract}

Keywords : radar, rainfall, short-term prediction, storm

\section{1. 序 論}

近年, 建設省によりデジタルレーダー雨量計が実用化 され，それに伴ってレーダー雨量計を用いた種々の短時 間降雨予測手法が提案されてきだ市 4). しかし，現在ま でに提案されている手法はすべて, 二次元平面内の降雨 パターンの変化傾向を時間的に外挿するといった運動学 的手法に属するもので，この運動学的手法では予測精度 に限界があるというのが現状である.

特に, 二次元平面内のデータの利用だけでは, 利用で きる降雨情報は三次元的に広がる降雨場のほんの一部分 に過ぎず, 他の気象データや気象学的知識とあわせて議 論する際に必要な, 降雨域の鉛直方向の広がり具合いや 強度分布等の情報は得られない. しかも二次元平面の情 報とはいうものの, それはレーダービームの仰角を一定 值に固定して得られる情報であるので，観測される現象 の高度がレーダーサイトからの距離によって異なるとい う点にも問題がある. したがって, さらに予測精度を向

* 正会員 工修 京都大学助手 防災研究所 (更611 宇治市五ケ布)

** 正会員 工博 京都大学助教授 工学部土木工学科 ( 606 京都市左京区吉田本町)

*** 正会員 工博 京都大学教授 防災研究所

**** 正会員 工博 京都大学教授 工学部土木工学科
上させるためには, 三次元レーダー雨量計(仰角可変レ一 ダ一雨量計）情報を利用した気象学的根拠のある降雨予 測手法の開発が不可欠となる.

一方, 国外, 特にアメリカにおいてはマルチセルやスー パーセル等の三次元構造の観測調查に関する多くの文献 があるものの ${ }^{5}$, わが国で発生する豪雨の降水系の三次 元構造およびその変動特性についての調查例はあまり多 くなく, 調查研究の究となっている. しかも, 湿潤で複 雑な地形を有するわが国で発生する強降水系の立体構造 やスケールが, 平坦な地形上の比較的乾燥した周囲の大 気の中で発生するアメリカの強降水系のそれらと異なる ことが十分予想されるので, 三次元レーダーによってわ が国の強降水系の三次元構造を解明することも基礎的研 究として重要な意味をもつことになる.

さて, 三次元レーダー雨量計情報の利用を考えるにあ たって, まず第一にレーダー雨量計データの分解能, つ まりレーダーデータがどの程度降水構造やその変動特性 を表現し得るかを前もって把握しておく必要がある. と ころが, 三次元空間内のレーダーエコーの強度分布を直 観的に把握することは容易ではない.なぜならば,一般 に三次元的なエコーの強度分布を二次元平面内に表現し ようとするとき, 三次元的なエコー域の形態をわかりや すく表現しようとすればその中の強度分布の表現が難し 


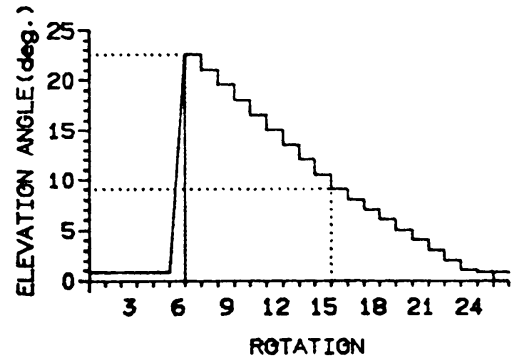

Fig. 1 Beam scanning procedure of the Miyama Radar Raingauge System.

くなるし，反対に強度分布の表現に重点をおけば立体的 なエコ一域の形態が直観的にはわかりにくいものとなる からである.

こういった点を考慮し，本研究ではカラーグラフィッ クスを用いて, 三次元的なエコーの強度分布を直観的か つ詳細に表現するための画像の開発を行うとともに，そ れらの画像を用いてレーダー雨量計データの分解能を調 ベることを目的とする.

なお用いたデー夕は, 昭和 61 年 7 月に京都府南部に 生じた集中豪雨時に建設省深山レーダー雨量計システム により観測されたものである.

\section{2. 三次元レーダー雨量計システム}

本章では, 三次元レーダー雨量計システムの概要を建 設省深山レーダー雨量計システムを例にとって説明する とともに, 放射状メッシュ単位に得られる受信電力值か ら三次元デカルト直交座標系内に設定した格子点上の值 への変換方針についても述べる.

\section{（1） 深山レーダー雨量計システムの概要}

建設省によって全国に配備運営されているレーダー雨 量計の数は 1987 年 3 月 31 日現在 13 台を数える. その なかで深山レーダー雨量計システムだけが，ビームの仰 角を固定した仰角固定観測のほかに, 仰角可変観測をも 行う機能を有する.

観測手順としては Fig. 1 に示すように, 1 分間に 5 回 転の回転速度で, ビームの最低仰角 $\left(0.8^{\circ}\right)$ とした仰角 固定観測を 1 分間と, 仰角が $22.5^{\circ}$ から $1^{\circ}$ までの仰角 可変観測を 4 分間の, 合計 5 分を 1 サイクルとして連続 観測を行う．したがって深山レーダーにおいては，仰角 可変観測時に最大仰角と最低仰角とでは観測時点に 4 分 の差が生じ，なおかつ仰角固定観測値だけは一分間平均 值であるので, 定量的な解析を行う場合, 対象とする時 空間スケールによっては，これらの点に注意をはらう必 要がある.

仰角固定観測時の受信電力値は,レーダーサイトを中 心とする半径 $120 \mathrm{~km}$ 以内を方位方向に 128 等分, 120

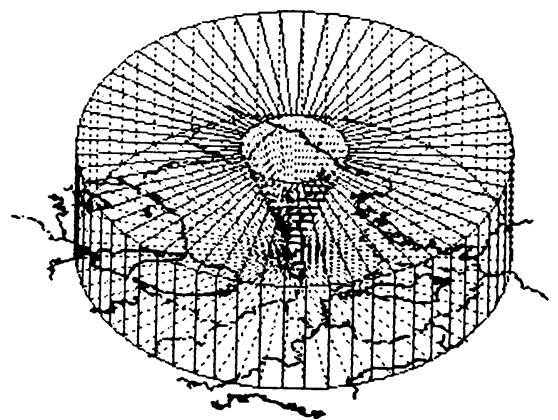

Fig. 2 Observation domain of the Miyama Radar Raingauge System.

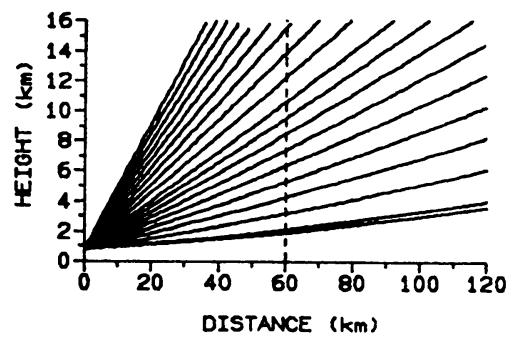

Fig. 3 Vertical section of the observation domain represented by radar lines of sight.

$\mathrm{km}$ から $198 \mathrm{~km}$ までを 256 等分して, さらにビーム方 向を $3 \mathrm{~km}$ ごとに等分して得られるメッシュ単位で与え られる. 半径 $120 \mathrm{~km}$ 以内が定量観測範囲，それ以外が 定性観測範囲之よばれている。これは，ブライトバンド の高さがおよそ $4 \mathrm{~km}$ と想定すると, 仰角固定観測時の ビームがこの高さを越えない範囲が $120 \mathrm{~km}$ 以内となる ためである.

一方，仰角可変観測範囲は地表面を平面とすれば Fig. 2 のとおりである. 半径 $120 \mathrm{~km}$ の円筒を, 地表か ら約 $15 \mathrm{~km}$ の高さで地表面に平行な平面で切った立体 にほぼ等しい，ただしビーム仰角が最大 $22.5^{\circ}$ という制 限から, 中心部には逆円錐状のデータのない領域がある. また底面も, ビームの最低仰角が 00 ではないのでレー ダーサイトを頂点とした逆円錐状をしている．この観測 範囲の鈶直断面をビーム走行線で表わしたのが Fig. 3 で ある.ビーム仰角は離散的に設定されており，ビームが 方位方向に一周する間, 仰角は一定値に保たれる. 図中, 最低仰角のビーム線は仰角固定観測時のものである. 各 仰角に対する観測範囲をビーム方向の距離で表わしたの が Table 1 である. 受信電力値は仰角固定観測時の定量 観測範囲之同様, 方位方向を 128 等分, ビーム方向を 3 $\mathrm{km}$ ごとに等分して得られるメッシュ単位で与えられ る.

（2）デカルト直交座標系内に設定した格子点上の 
Table 1 Observation range for each elevation angle.

\begin{tabular}{c|c|c}
\hline No. & $\begin{array}{c}\text { elevetion } \\
\text { angle(deg.) }\end{array}$ & $\begin{array}{c}\text { observation range } \\
\text { along radar lines } \\
\text { of sight (km) }\end{array}$ \\
\hline $1^{*}$ & 0.8 & 120 \\
2 & 1.0 & 120 \\
3 & 2.0 & 120 \\
4 & 3.0 & 120 \\
5 & 4.0 & 120 \\
6 & 5.0 & 120 \\
7 & 6.0 & 120 \\
8 & 7.0 & 120 \\
9 & 8.0 & 108 \\
10 & 9.0 & 96 \\
11 & 10.5 & 84 \\
12 & 12.0 & 72 \\
13 & 13.5 & 63 \\
14 & 15.0 & 57 \\
15 & 16.5 & 51 \\
16 & 18.0 & 48 \\
17 & 19.5 & 45 \\
18 & 21.0 & 42 \\
19 & 22.5 & 39 \\
\hline$:$ for the observation with fixed elevetion \\
angle & & \\
& &
\end{tabular}

\section{データ值への変換}

（1）で述べたように，レーダーの受信電力値は，方 位方向と距離方向の極座標系で表現される放射状メッ シュ単位で得られる，しかし，降水強度分布の三次元画 像を作成したり各種の解析を行うにあたり，データの空 間的配置は直交座標系で表わされている方が都合がよ い.したがって本研究では, Fig. 4 に示す単位放射状メッ シュごとに得られる值を,三次元デカルト直交座標系(以 下では単に直交座標系とよぶ）における格子点上の值に 変換する. 図中, $1.35^{\circ}$ はアンテナの垂直ビーム幅であ る．具体的には，各格子点がどの単位放射状メッシュに 含まれるかを判断し，その単位放射状メッシュ内の平均 受信電力値をもって，格子点上の值とする.

ただし，本研究では三次元的な観測域全体を単位放射 状メッシュで分割構成できるようにするために，単位放 射状メッシュの上下端は，Table 1 のNo. $n$ に対する仰 角を $\alpha(n)$ ，この仰角に対する単位放射状メッシュ上面 の仰角を $\alpha_{u}(n)$, 下面の仰角を $\alpha_{l}(n)$, として

$$
\left.\begin{array}{l}
\alpha_{u}(n)=\{\alpha(n+1)+\alpha(n)\} / 2 \\
\alpha_{l}(n)=\{\alpha(n)+\alpha(n-1)\} / 2
\end{array}\right\}
$$

のように定めることにする．ただし，

$$
\alpha_{l}(1)=0.2^{\circ}, \quad \alpha_{u}(19)=23.0^{\circ} \ldots
$$

とする．なお，アンテナの垂直ビーム幅は $1.35^{\circ}$ である ので，仰角が $9^{\circ}$ 以上になると単位放射状メッシュ内に ビームの Major Lobe の走行しない領域が若干存在する ことになるが，これは無視する.

直交座標系および格子点は以下のようにして定める.

Fig. 5 に示すように，円筒形をしている観測範囲を含む ような $240 \mathrm{~km} \times 240 \mathrm{~km} \times 13 \mathrm{~km}$ の直方体を，レーダー

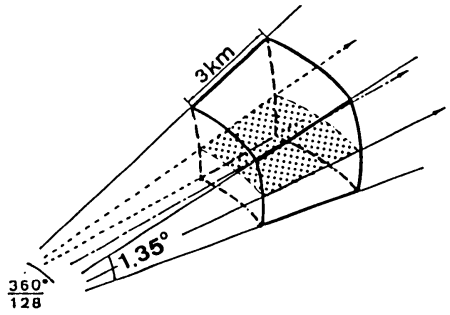

Fig. 4 Illustration of a unit mesh. The electronic power intensity averaged within this unit domain is recorded.

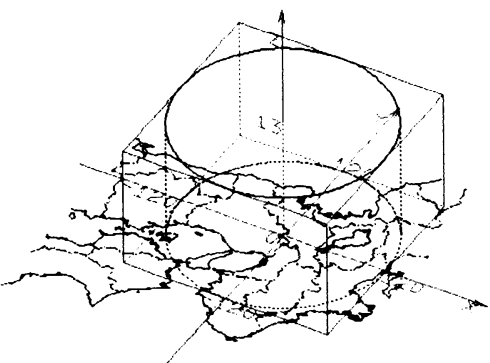

Fig. 5 Rectangular cartesian coordinate system set over the Kinki District.

サイトを中心に東西方向を $x$ 軸，南北方向を $y$ 軸，鉛 直方向を $z$ 軸とした直交座標系に設定する．直方体の 高さを $13 \mathrm{~km}$ としたのは, 対流圏界面のおよその高度 と，計算機の記憶領域の節約とを考慮したためである.

次に，設定した直方体を $x$ 軸， $y$ 軸方向にそれぞれ 80 等分， $z$ 軸方向に 13 等分して得られる. $3 \mathrm{~km} \times 3$ $\mathrm{km} \times 1 \mathrm{~km}$ のメッシュで構成し, このメッシュの中心点 を格子点とする. ただし，高度 $0.5 \mathrm{~km}$ の格子点はすべ て観測範囲には含まれない。ここで格子点の $z$ 軸方向 の間隔を $1 \mathrm{~km}$ としたのは, レーダー観測範囲の鉛直方 向の平均的な分解能が $1 \mathrm{~km}$ であることによる。つまり Fig. 2 で示したように, 仰角可変時の観測範聿半径 120 $\mathrm{km}$ の中間点，すなわち $60 \mathrm{~km}$ 地点におけるレーダー ビームの鉛直方向の分解能が約 $1 \mathrm{~km}$ であることによ る.

ところで, 厳密には地表は平面ではない, そこで,レー ダーサイトを中心とした正距方位図上に直交座標系を設 定するものと考える. そうすれば, 地図上の地点 $(x, y)$ はレーダーサイトから方位 $\theta(=\arctan (y / x))$ 方向に 地表に沿って距離 $r\left(=\left(x^{2}+y^{2}\right)^{1 / 2}\right)$ だけ進んだ地点を 正確に表現していることになる.

さて, 格子点の地表面に沿った距離 $r$, 高さ $z$ が定 まると,レーダーサイトからみた格子点の仰角 $\alpha$, 距離 $d$ (Fig. 6 参照) を

$$
\alpha=\arctan \left\{\cot \phi-\frac{\left(R+z_{0}\right) /(R+z)}{\sin \phi}\right\}
$$


$d=\left(R+z_{0}\right) \sin \phi / \cos (\phi+\alpha)$

$\phi=r / R$

に従って求める.ただし, $R$ は地球の半径, $z_{0}$ はレーダー サイトの標高である.

このようにして， $\theta, \alpha, d$ が定まれば，格子点を含む 単位放射状メッシュが決定できるので，この単位放射状 メッシュの平均受信電力值を格子点上の受信電力値とす る.

\section{3. 三次元レーダー雨量計情報の可視画像}

本章では, 三次元的なエコーの広がりおよび強度分布 を表現しようとして, カラーグラフィックスを用いて作 成した種々の画像を紹介する. 画像はすべて, ソニー・ テクトロニクス社製グラフィック・ライブラリー PLOT 10 ・ IGL を利用して FORTRAN 77 でプログラ ミングし, 同社製 4109 型カラーグラフィック端末によっ て作成した。

\section{（1）三次元的なエコー域形態の表現画像}

Fig. 7 は等価レーダー反射因子強度（以下，単に反射 因子強度あるいはエコー強度とよぶ）が $10 \mathrm{dBZ}$ 以上の 降水域の最高高度の分布を三次元的に表現して, 降水域 の三次元的形態を表わそうとしたものである. 降水域を 雲にたとえれば，雲頂高度の分布図といえる．必ずしも すべての場合とはいえないが，降水域の下にはやはりエ コーが存在するとすれば，この図は三次元的な降水域の 形をほぼ表現していることになる.なお，図中の半径 $120 \mathrm{~km}$ の円は，この円内がレーダーの観測範囲である ことを表わす.

一方, Fig. 8 は反射因子強度が $20 \mathrm{dBZ}$ 以上の格子点 を含む, $3 \mathrm{~km} \times 3 \mathrm{~km}$ の正方形メッシュを高度ごとに色 分けして塗りつぶすことによって, 降水域の立体的な姿 を可視化したものである．高度ごとに異なった色を用い

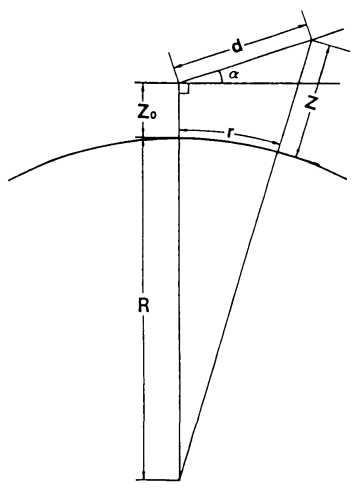

Fig. 6 Explanation of the relation among the elevation angle $\alpha$, the distance from the grid point to the radar site $d$ and the height of the grid point $z$.

ることにより, 各高度の降水域の重なり具合いを表現し ている.現場においても三次元的形態を即座に判断する のに十分な画像である．ここで，下面の地図上に赤色で 描いてある矢印は，アメダス地上風から線形内挿して求 めたおよその地上風速場である.これは, 降水系の三次 元的形態亡, 主な水蒸気の供給源である下層大気の流入 場6) との関係をも定性的にではあるが現場においても即 座に判断しやすくするために設けたものである.なお， 矢印は矢先の地点の風速べクトルを表わし, その長さは 時速で表わした風速の 2 倍にしてある.

これらの画像は任意の閾値を選ぶことによって任意の 強度以上の降水域の形態を表現することができる.

（2）三次元エコー強度分布図 (VCAPPI, RRHI)

降水域の三次元的輪郭と強度分布とを同時に画像に表 現すること, つまり降水域の空間的な全体像を生かしつ つ内部の強度分布もわかるようにすることは, 三次元エ コー強度分布を取り扱うにあたって理想とすべきことで

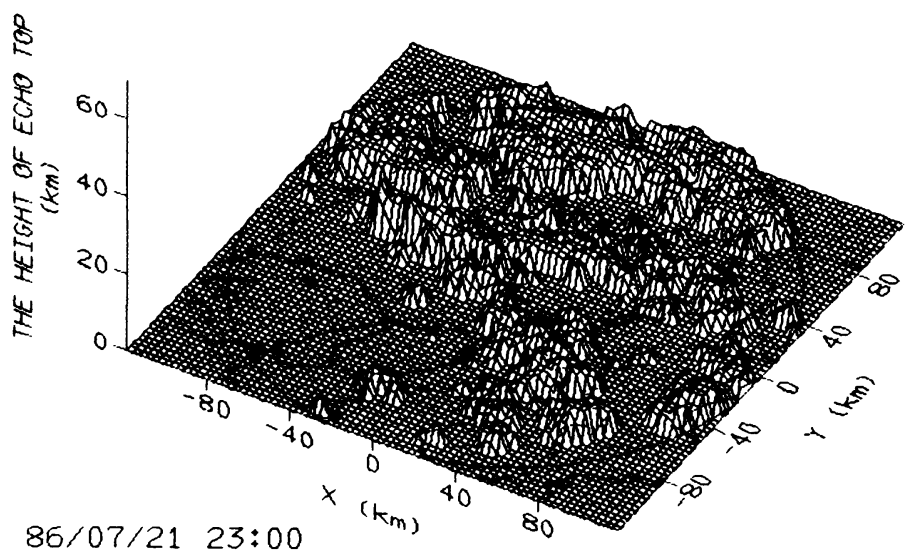

Fig. 7 Distribution of the height of the top grid point at which the radar reflective factor greater than $10 \mathrm{dBZ}$ can be detected. 


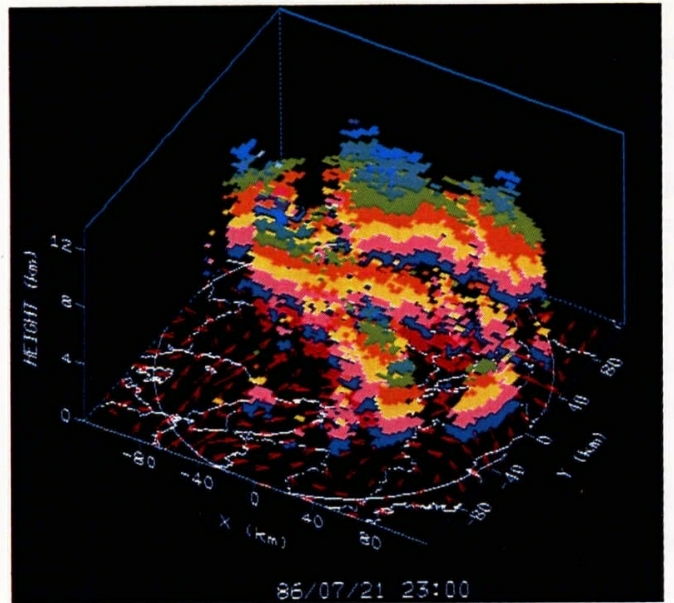

Fig. 8 The shape of the three dimensionally spread precipitation field.

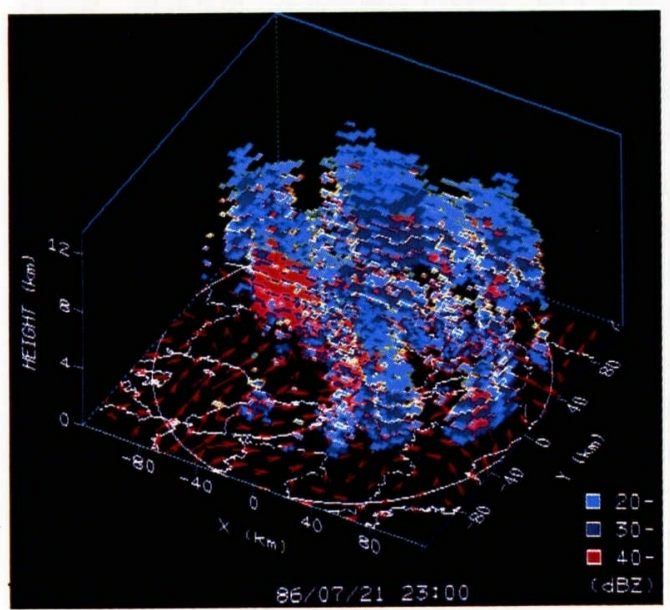

Fig. 9 VCAPPI

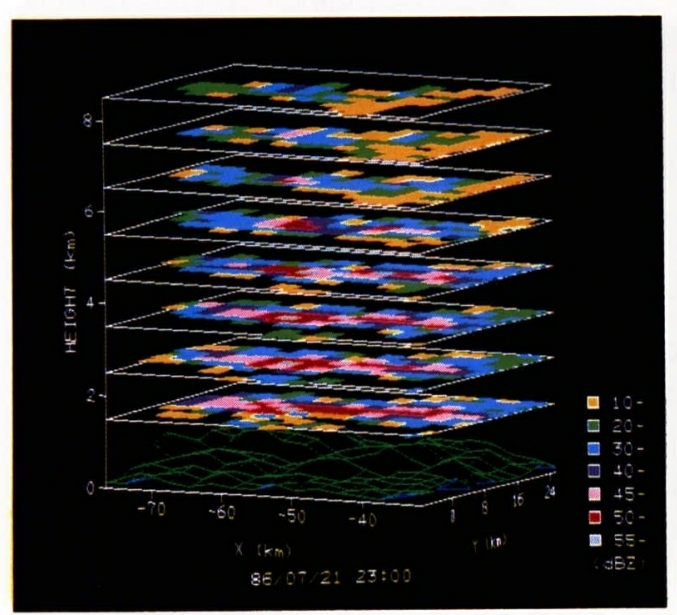

Fig. 10 FVCAPPI (VCAPPI for an arbitrary specified domain).

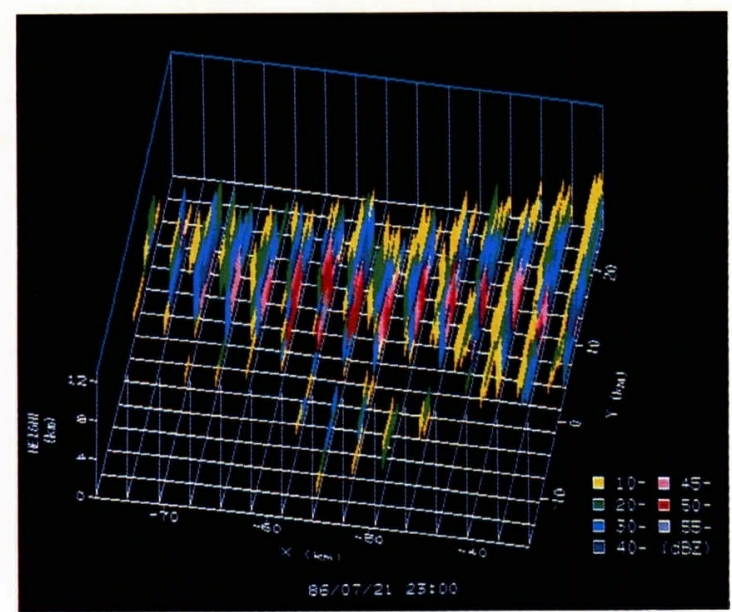

Fig.11 RRHI with north-south vertical sections.

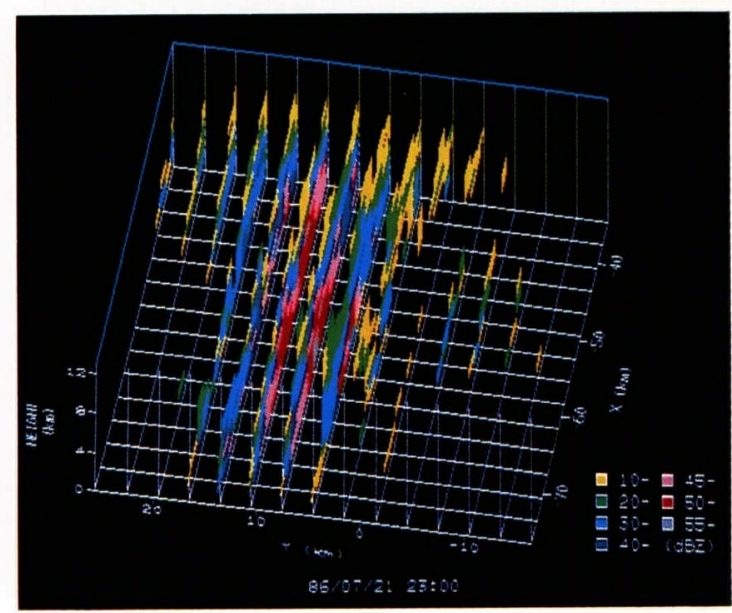

Fig. 12 RRHI with east-west vertical sections.

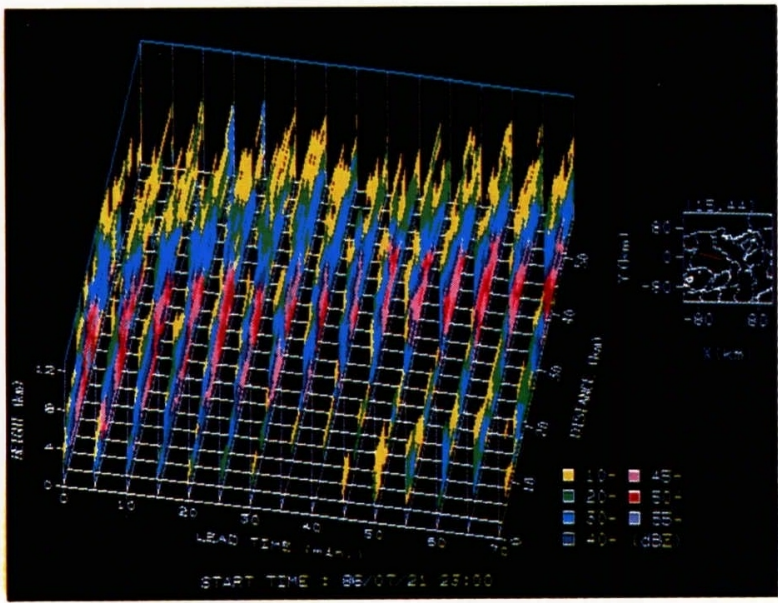

Fig. 13 RHTI with the vertical section along the storm moving direction. 
ある. 本研究では, 強度分布を描いた平面を三次元空間 に並べて表示することによって，これを実現しようとし た。

強度分布を平面に描いたものとしてまず，CAPPI (Constant Altitude Plan Position Indicator) が挙げ られる。これは, レーダービーム走行面の強度分布を表 示する PPI (Plan Position Indicator) と異なり，一定 高度面のエコーの強度分布を表示するものである.

そこで, 各高度の CAPPI を三次元空間に並べて表示 したのが Fig. 9 である.これは, 降水域を高度ごとに色 分けして三次元的形態を表現した Fig. 8 を改良し，おの おのの高度の降水域を一色で塗りつぶすのではなく，エ コーの強度によって色分けしたものといえる。ただし， 以下に示す強度分布図とは違い，この図だけは煩雑にな るのを避けるために 3 色で表わしてある. さらに，降水 域の重なり具合いもわかるように Fig. 8 のカラ一画像で 平面を塗りつぶしたのと同じ色の輪郭線を設けてあるの で, 降水域の三次元的な輪郭も直観的に読み取ることが できる．兵庫県中央部あたりに高高度まで伸びる強降水 域が存在するのが読み取れる. 前述したようにこの画像 は各高度の CAPPI を重站わせた図であるので, これをVarious Constant Altitude Plan Positions Indicator，すなわち VCAPPI とよぶことにする.

この VCAPPI を限られた範囲内だけに限定し, 各高 度の強度分布図が互いに重なり合わないようにして高度 $1.5 \mathrm{~km}$ から $8.5 \mathrm{~km}$ までの三次元エコ一強度分布を表わ したのが Fig. 10 である.ここで表現されているのは Fig. 9 で兵庫県中央部上空かなりの高度まで $40 \mathrm{dBZ}$ 以 上の強エコーがのびていた降水域で, これが実はいくつ かのかなり発達した深い対流性エコーからなっているこ とがわかる. Fig. 9 と異なり, エコー強度が $40 \mathrm{dBZ}$ よ り大きい部分は $5 \mathrm{dBZ}$ ごとに色分けしてより詳細に強 度分布が読み取れるようにしてある. なお最下層の強度 分布の下に描いてある緑の網線は山岳地形を表わす。こ の画像によれば, 水平面内の詳細な強度分布のほかその 鉛直方向のつながり具合いも容易にわかるため, 降水域 の三次元形態とともにその立体的な強度分布も直観的か つ詳細に把握することができる.

さて, Fig.9，Fig.10ともに分類上はVCAPPI に属 するものであるが, 前者をVCAPPI, 後者を FineVCAPPIつまり FVCAPPI とよぶことにする.

次に，鉛直断面内の強度分布を表示する画像として RHI (Range Height Indicator) がある. 本来の RHI とは、レーダーサイトから一定方位方向に沿った距離を 横軸に，高度を縦軸にとることによって，レーダーサイ 卜を通る任意方向の鉛直断面内のエコ一強度分布を表示 するものである7)。本研究ではレーダーサイトを通る鋁
直断面だけでなく任意の鉛直断面内における強度分布図 をRHI とよぶことにする.

この RHI を隠れた部分が生じないように三次元空間 内に並べて, Fig. 10 と同じく兵庫県中央部に存在した 強降水域の三次元強度分布を表現したのが Fig. 11 およ び Fig. 12 である. Fig.11 は南北断面の RHI 15 枚を東 西方向に並べたものである. 表現されている領域は 42 $\mathrm{km} \times 42 \mathrm{~km}$ の正方形領域であり, $x$ 軸の正方向が東, $y$ 軸の正方向が北である.この画像によっても，降水域全 体の形態や，その中の強降水域の位置や形態がよくわか る. さらに鉛直方向のスケールと水平方向のスケールと がほぼ一致するよう考慮されているので, 画像から直観 的に読み取れる強度分布形態はより現実に近いものと なっている. 一方 Fig. 12 は, 同じ領域内の東西断面の RHI を 15 枚並べたものである. 図の向きは, Fig. 11 を 反時計回りに 90 度回転させてある. したがって，底面 の横軸が $y$ 軸, 縦軸が $x$ 軸である. 南北断面, 東西断 面のどちらの RHI を並べるかによって若干受ける感じ が異なってくるが，ぼちらの方向のつながりに重きをお くかによって使い分ければよい. 通常の RHI が Range Height Indicator であるのに対して,この画像は Height の代わりに Range Height を表現しているので, 以後 RRHI とよぶことにする.

さて, Fig.10, Fig.11, Fig.12に示した画像は, 数 十 $\mathrm{km}$ 四方の領域上空のエコ一強度の三次元的な分布を 直観的かつ詳細に把握, 調查できるという点において, 本研究の目的とする画像であり, いくつもの対流セルを 含むマルチセル型雷雨など複雑な構造をもつ雷雨の解析 等に非常に有効である. 特に対流性エコーを力学的ある いは熱力学的に調查する場合には鈆直面内の強度分布が 対象の中心となることを考えれば，鉛直面内の強度分布 によってエコー強度の三次元構造を表現した RRHI は 今後の調査において最も有用な画像といえる.さらに （1），（2）で示した 5 種類の画像をあわせて利用すれ ば, 巨視的・微視的双方の観点から降水域の三次元構造 およびその発達・衰弱の様子を捉えることが可能とな る.

\section{（3）エコー強度分布の時間推移の表現画像（RHTI）}

ここまでは, ある時刻における降水域の表現画像を示 してきた. 強度分布の時間推移を知るためにはこれらの 画像を時間ごとに並べてゆけばよい。しかし，時間推移 をより直観的に把握するためには座標軸の 1 つに時間軸 を取り入れた画像を用いた方がよい。

すでに時間軸を導入した画像の 1 つとして, 横軸に時 間, 縦軸に高さをとって, ある地点の鉛直軸に沿った強 度分布の時間変化を表わしたHTI (Height Time Indicator）がある71. 本研究ではこれを三次元表示画像 
に発展させ，鉛直軸方向の強度分布の代わりに任意の鉛 直断面の RHI を用いた画像を作成し，これを Range Height Time Indicator，すなわちRHTI とよぶことに した.これはRRHI $の ~ x$ 軸, $y$ 軸のいずれかを距離軸に, もう一方を時間軸にとって, 降水域の任意の鉛直断面に おける強度の時間変化を表わしたものに相当する. しか し, HTI とは異なりRHTI は鉛直平面内の強度分布の 時間変化を表わすものであるから, 設定される鉛直断面 はエコーの進行方向でなければあまり意味がない。なぜ ならば, 画像上の強降水域が発生したり消滅していくの が, エコー自体の消滅によるものなのか, それとも単に エコーが断面を横切ることによって消滅したかのように みえるだけなのか, 判断することはできないからである. したがって特定の降水域を追跡してその内部構造の変化 を調查する場合, 設定する断面はエコー進行方向に沿っ たものでなければならない。

そこで，降水域の進行方向に沿った鉛直断面内の強度 分布の 5 分ごとの時間推移を表わしたのが Fig. 13 であ る. 地図上に描いてある赤線は, この線上の鉛直断面内 の強度分布を描いてあることを意味する．また，この線 の左端が距離方向の始点である. 時間軸に記してある数 值は, START TIME と記してある開始時刻から何分 後であるかを意味する，この図の場合，たとえば時間軸 で 60 の位置にある断面は, 開始時刻の 86 年 07 月 21 日 23 時 00 分から 60 分後, すなわち 22 日 00 時 00 分にお ける RHI である.ここで，降水域の進行方向は，21 日 23 時 00 分から 22 日 00 時 00 分までの 5 分ごとの RRHI 13 枚によって対流性エコーを追跡して定めた.

この図では $50 \mathrm{dBZ}$ 以上の強エコーがほぼ全断面に現 われているのが確認できる。これは, 進行方向に沿った ものとして設定した鉛直断面をエコーセルがあまり横 切って通過しなかったことによるものと考えられる.こ のように降水域の進行方向をも考慮したRHTI を用い ることによって, エコー強度の時間変化や内部のセルの 発達・衰弱の様子をより直観的かつ正確に調べることが 可能となる.

\section{（4）三次元レーダー雨量計情報の分解能}

さて序論でも述べたように，三次元レーダー雨量計情 報を用いるにあたって，まずレーダーデータの分解能， つまりレーダーデータがごの程度小スケールの降水構造 や変動特性を表現し得るかを把握しておく必要がある. そこで，ここでは紹介した画像に表わされている降水域 の定性的な特徵を述べながら，レーダーデータの分解能 を明らかにする。

まず Fig. 10～Fig. 12 からまず気がつくことは，南北 方向と東西方向の降水域の広がりの違いで, 南北断面は 1 つの対流性エコーから, 東西断面は数個の対流性工
コーから成り立っているのがわかる．最大の対流性エ コーのエコー頂高度は $13 \mathrm{~km}$ 程度, $50 \mathrm{dBZ}$ 以上の部分 に注目すればその直径は $10 \mathrm{~km}$ を越え，かなり発達し た対流性エコーであることがわかる。これらのことは以 下のように定性的に説明できる．まず Fig. 10 をみると， 上空にエコーが存在するのは南向き斜面あるいはその頂 上部付近であることがわかる。このことは地形と高度 $2.5 \mathrm{~km}$ のエコー強度分布の重ね合わせ図である Fig. 14 をみればよりはっきりと確認される，ただしこの図は強 度分布を高度 0 の面内に描いてある.したがって,

Fig. 9 ともあわせて判断すれば, 兵庫県南部の平野を 通って流入した湿潤な下層大気が県中央部の山岳斜面に よってもともと潜在不安定な場の中で強制上昇させら れ，自由対流高度を越えたことが，このかなり発達した 対流性エコーの発生あるいはこの位置での発達の一因で あることは確かである。一方，米子および潮岬の 21 日 21 時の観測によれば $700 \mathrm{mb}$ 高度から対流圈界面を越え たかなりの高度まで $10 \mathrm{~m} / \mathrm{s}$ 前後の西ないしは西北西の 風が一定して吹いており, 発生した対流性エコーがこの 風によって東方あるいは東南東に流されるために東西方 向に対流性エコーが並んでいるものと考えられる。

さて，この対流性エコーの進行方向 (Fig.13参照) に沿った鉛直断面の RHI が Fig. 15 である. エコーの進 行方向は右側である.なお横軸に沿って㙦りつぶしてあ る部分は山岳地形を表わす。この図からこの対流性工 コーはマルチセル型雷雨によるもので，中心部に存在す る強エコ一域では下降流が卓越しているものと考えられ

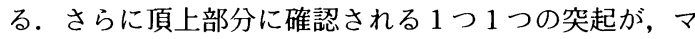
ルチセル型雷雨を構成している個々の対流セルに対応し ているものと思われる．序論でも述べたようにわが国と アメリカとでは周囲の大気の湿度が異なることなどから 若干スケールの違いがあるものの，この図はしばしば引 用されるアメリカで観測されたマルチセル型雷雨の構造

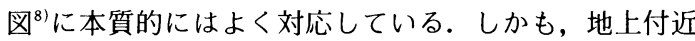
では南方風，上空では地上風にほぼ垂直方向であるエ コーの進行方向と同じ風向の風となっており，マルチセ ル型雷雨が発生しやすい状況であった。 さらに, Fig. 15 と同じ断面内の強度分布の時間推移を表わしている Fig. 13 からもマルチセル型雷雨の特徵が見出される. 必ずしもきれいなパターンにはまったものではないもの のこの画像によるとエコー進行方向前方で新たに強エ コーが発生し，後方では減衰してゆく様子を読み取るこ とができる．このことは東西断面を用いた RRHI を時 間を追ってみてゆくことでも確認される.

以上より，三次元レーダー雨量計データを用いること により，いくつかの対流セルから成っている雷雨に関し ては内部構造やその変化の様子まで確認できることがわ 
かる. さらに, レーダーのもともとの解像度から考えれ ば1つ1つの積雲に対応する対流セルの内部構造までは 確認できないものの, 対流セルの存在および発生・消滅 はほぼ確認できることもわかる.

\section{4. 結 論}

以上，三次元的なエコーの強度分布を直観的に表現す るために作成した画像を紹介し，それらの画像を用いて 三次元レーダー雨量計データによってどの程度の分解能 で降水強度分布特性やその変動特性を表現し得るかを明 らかにするとともに，それらの特性とルーチン観測によ る若干の気象データや地形との定性的な関係について述
ベた.

開発した画像は次の 3 つに分類される.

(1) レーダー観測範囲内全体といった，やや大きなス ケールでみた降水域の三次元的な広がり具合いを表 現する画像 (Fig.7, Fig.8),

(2)もう少し小さな範囲内における降水域の強度分布 の三次元的な表現画像である FVCAPPI および RRHI とその時間推移の表現画像 RHTI (Fig. 10 Fig. 13),

(3)これらの中間的な意味合いをもっVCAPPI (Fig. 9).

ここで, スケールで分類すれば, (1), (3)がメソ $\beta$ スケー

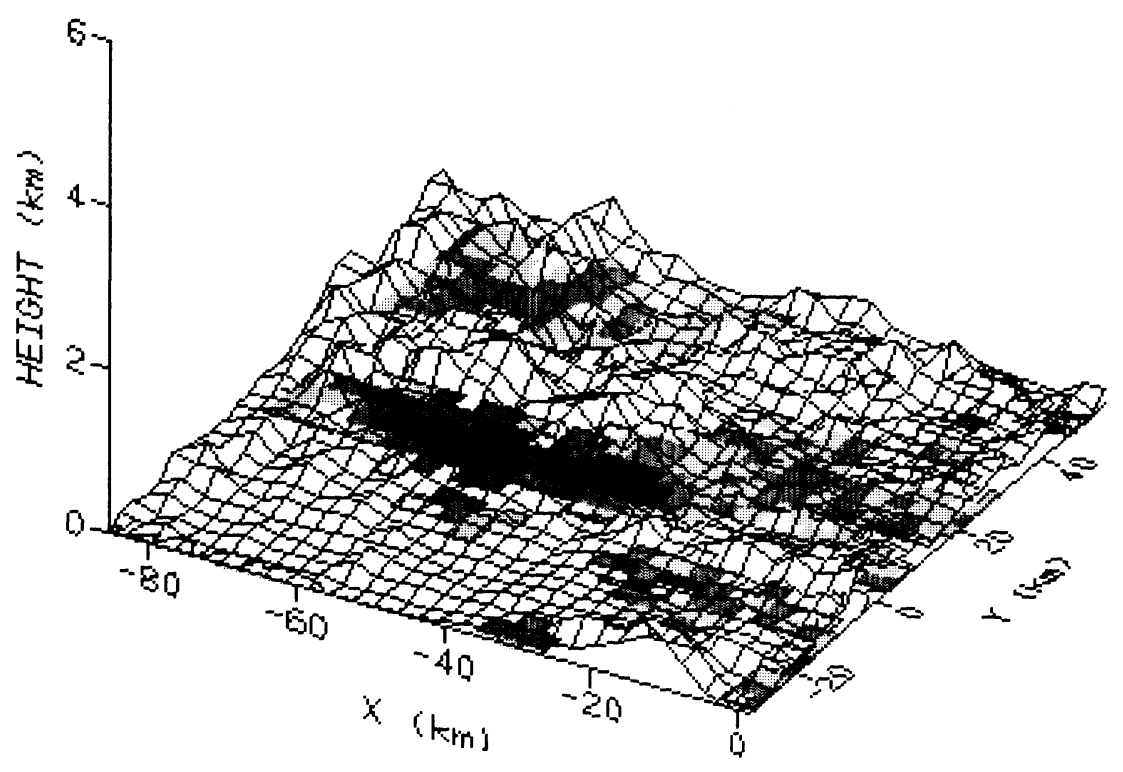

\section{$86 / 07 / 2123: 00$ (2.50 km height] $10-\square 20-\square 30-\square 40-\square 50-【 d B E$ ।}

Fig. 14 Composition of the distribution of echo intensity at $2.5 \mathrm{~km}$ height and the configulation of the ground.
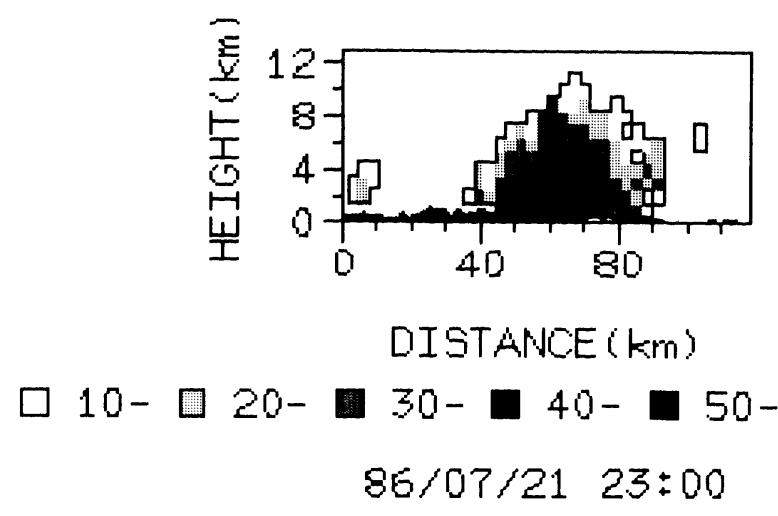

Fig. 15 RHI along the storm moving direction. 
ル $\left(20 \sim 200 \mathrm{~km}\right.$ の水平スケール $\left.{ }^{9)}\right)$, (2)がメソ $\gamma$ スケー ル $(2 \sim 20 \mathrm{~km}$ の水平スケール) でみた現象を表現して いることになる. 一方, 強度分布も表現されているかど うかで分類すれば，(1)は降水域の形態のみの，(2)，(3)は 両者を兼ねた画像である，したがって，(3)は(1)，(2)の中 間的な特徵をもった画像といえる.

まず，(1)，(3)の画像の開発により，レーダー観測域全 体でみた降水域の三次元形態や強度分布を容易に概観で きるようになった。一方，特定の強降水域の三次元的輪 郭と詳細な強度分布とを同時に画像上に表現する FVCAPPI，RRHI の開発により，メソ $\gamma$ スケールで みた三次元的なエコ一強度分布を直観的に把握すること ができるようになった. マルチセル型雷雨を例にとりあ げれば，それが発達段階の異なるいくつかのセルから 成っていることが確認できる程度までの分解能のあるこ とがわかった。また RHTI の開発によって鉛直断面内 のエコー強度の時間変化はもとより, エコー進行方向の 鉛直断面を設定することで，たとえばマルチセル型雷雨 についてはそれを構成している各セルの発生・衰弱の様 子をも直観的に追跡調査できるようになった。

中でも, FVCAPPI, RRHI は数十 $\mathrm{km}$ 四方の領域上 空のエコー強度の三次元的な分布を直観的かつ詳細に把 握, 調査できるという点において, 本研究の目的とする 画像であり, 特に対流性エコ一を力学的あるいは熱力学 的に調查する場合には鉛直面内の強度分布が対象の中心 となることを考えれば, 鉛直面内の強度分布によってエ コ一強度の三次元構造を表現した RRHI は今後の調査 において最も有用な画像といえる.さらに 5 種類すべて の画像をあわせて利用すれば，巨視的・微視的双方の観 点から降水域の三次元構造およびその発達・衰弱の様子 を捉えることが可能となる.

今後はこれらの画像を用いて, 他の豪雨現象も含めた
種々の降水域の三次元的構造およびその変動特性を気象 データとからめて調查してゆく予定である.

最後に, 本研究で用いた深山レーダー雨量計データは 建設省近畿地方建設局淀川ダム統合管理事務所から提供 して頂きました。その際，広域水管理課と電気通信課の 方々にはたいへんなご面倒をおかけしました。心からお 礼申し上げます.さらに, 当時京都大学大学院生の筒井 雅行君と学部学生の小林 仁君には図表の作成等を手 伝って頂きました.ここに，謝意を表する次第でありま す.

\section{参 考 文 献}

1）立平良三・牧野義久：デジタル化されたエコーパターン の予測への利用, 研究時報, Vol. 26, pp. 188 199, 1974.

2) Austin, G.L. and Bellon, A. : The use of digital weather record for short-term precipitation forecasting, Quart. J.R. Met. Soc., Vol. 100, pp. 658 664, 1974.

3）大倉 博・石崎勝義・中尾宏臣・森本陸世：レーダ一雨 量計を用いた短時間降雨予測, 第 27 回水理講演会論文集, pp. 349 354, 1983.

4）椎葉充晴・高棹环馬・中北英一：移流モデルによる短時 間降雨予測手法の検討, 第 28 回水理講演会論文集, pp. 423 428, 1984.

5) Agee, E. M. and Asai, T. : Cloud dynamics, D. Reidel Publishing Company, 1982.

6)二宮洸三・秋山孝子：豪雨の水収支, 気象研究ノ一ト, 第 138 号, pp. 91 117, 1979.

7) Battan, L. J. : Radar observation of atmosphere, The University of Chicago Press, 1973.

8）小倉義光：一般気象学, 東京大学出版会, 1984.

9) Orlanski, I. : A rational subdivision of scale for atmospheric process, Bull. Amer. Met. Soc., Vol. 56, pp. 527 $\sim 530,1975$.

(1987. 10.16 · 受付) 